\title{
KEUNTUNGAN USAHA PENGOLAHAN LEMPOK DI KECAMATAN TEBING TINGGI KABUPATEN EMPAT LAWANG
}

\author{
Nila Suryati \\ Dosen pada Prodi Agribisnis Universitas Musi Rawas \\ Email: suryatinila@ymail.com

\section{BENEFIT ANALISYS OF LEMPOK INDUSTRY AT TEBING TINGGI DISTRICT EMPAT LAWANG REGENCY} \\ Nila Suryati \\ Lecturer at Program Study Agribusiness of Musi Rawas University \\ Email: suryatinila@ymail.com
}

\begin{abstract}
Durian (Durio zibethinus Murray) is one of tropical fruit in Indonesia. Durian can be processed to be any kind of food, such as Lempok. Lempok in Tebing Tinggi District Empat Lawang Residence was managed in household scale to small industry. The purpose of this research was to analyze production cost and benefit of lempok durian industry at Tebing Tinggi District Empat Lawang Residence. Research methode used on this research was case study, with respondence choosen purposively. From this research found that average production cost of this lempok industri as much as Rp. 151.255.732-, consist of average fixed cost Rp. 1.133.951 and average variable cost Rp. 150.121.781,-. Meanwhile the benefit value of this product was Rp. 188.769.268 per year, obtained from 4.225 kilogram lempok and 81 kilogram crust of lempok per year.
\end{abstract}

Key Word: Benefit, Durian, Lempok

\begin{abstract}
Abstrak
Durian (Durio zibethinus Murray) adalah salah satu buah tropis yang menjadi primadona di Indonesia. Selain dikonsumsi segar, durian juga dapat diolah menjadi berbagai jenis panganan yang juga sangat banyak digemari. Buah durian segar dapat diolah menjadi berbagai jenis produk makanan siap konsumsi Daging buah durian salah satunya dapat diolah dan dijadikan bahan baku utama pembuatan lempok. Lempok durian di Kecamatan Tebing Tinggi Kabupaten Empat Lawang dikelola mulai dari skala rumahtangga sampai industri kecil.

Tujuan dari penelitian ini adalah untuk menganalisa biaya produksi dan keuntungan usaha pengolahan lempok durian di Kecamatan Tebing Tinggi Kabupaten Empat Lawang. Metode penelitian yang digunakan adalah metode studi kasus, sedangkan penentuan responden dilakukan secara sengaja (purposive).

Hasil penelitian menunjukkan bahwa, biaya produksi yang dikeluarkan untuk pengolahan durian menjadi lempok adalah rata-rata sebesar Rp. 151.255.732-, yang terdiri dari rata-rata biaya tetap Rp. 1.133.951 dan rata-rata biaya variabel Rp. 150.121.781,-.
\end{abstract}


Sementara keuntungan yang diperoleh dari usaha pengolahan durian menjadi lempok ratarata $\mathrm{Rp}$. 188.769.268 per tahun, yang diperoleh dari hasil penjualan 4.225 kilogram lempok dan 81 kilogram kerak per tahun.

Kata Kunci: Durian, Keuntungan, Lempok

\section{PENDAHULUAN}

\subsection{Latar Belakang}

Durian (Durio zibethinus Murray) adalah salah satu buah tropis yang menjadi primadona di Indonesia. Buah yang juga dikenal dengan julukan King of Fruits ini selalu dinantikan kehadirannya. Rasa dan aroma khas yang dimiliki buah durian membuatnya sangat digemari oleh sebagian orang. Nama durian diberikan kepada buah ini karena seluruh kulitnya yang keras dan berlekuk-lekuk tajam seperti duri (Sunarjono, 2005).

Buah durian tidak berproduksi setiap bulan dalam satu tahun. Tanaman ini termasuk jenis tanaman buah musiman yang hanya bisa dipanen pada musim-musim tertentu saja. Musim panen buah durian di Sumatera Selatan biasanya berlangsung antara bulan Oktober sampai Februari. Buah durian yang matang akan jatuh dengan sendirinya. Dalam satu pohon jumlah durian yang bisa dipanen berkisar antara 60 sampai 70 butir per tahun dengan bobot rata-rata 2,7 kilogram (Sunarjono, 2005).
Sebagaimana komoditas pertanian pada umumnya, buah durian mempunyai sifat mudah rusak. Dengan sifat ini buah durian sebaiknya langsung dikonsumsi saat masih segar. Hal ini menyebabkan harga buah durian cenderung menurun saat musim panen tiba. Sebaliknya saat musim panen selesai harga jual buah durian akan melejit seiring dengan ketersediaannya yang semakin sedikit. Oleh sebab itu durian memerlukan pengolahan lebih lanjut agar nilai ekonominya lebih baik.

Selain dikonsumsi segar, durian juga dapat diolah menjadi berbagai jenis panganan yang juga sangat banyak digemari. Buah durian segar dapat diolah menjadi berbagai jenis produk makanan siap konsumsi. Daging buah durian dapat diolah dan dijadikan bahan baku utama pembuatan lempok, pancake, dan bahkan bisa diolah bersama sama kopi menjadi kopi durian.

Salah satu daerah penghasil durian di Sumatera Selatan adalah Kabupaten Empat Lawang. Buah durian tumbuh dan berkembang di hampir semua wilayah 
Kabupaten Empat Lawang termasuk di Kecamatan Tebing Tinggi. Produksi buah durian di Kecamatan Tebing Tinggi lebih tinggi dibandingkan dengan produksi tanaman buah lain yang ada disana. Pada tahun 2019 produksi buah durian di Kecamatan Tebing Tinggi sebanyak 6.384 kuintal (BPS, 2019).

Produksi durian yang tinggi di Kecamatan Tebing Tinggi memunculkan usaha-usaha pengolahan lempok durian. Lempok durian adalah panganan yang rasanya manis, berbentuk makanan semi basah yang berbahan baku durian (Lestari, 2000). Mutu buah durian dan aromanya yang tajam harus dipertahankan kualitasnya karena turut mempengaruhi lempok durian yang diproduksi. Pelaku industri lempok durian yang memiliki modal dan persediaan bahan baku yang lebih besar akan dapat menjual lempok durian dalam jumlah yang besar (Mursida, 2008).

Lempok durian di Kecamatan Tebing Tinggi dikelola mulai dari skala rumahtangga sampai industri kecil. Data Dinas Perindustrian dan Perdagangan Kabupaten Empat Lawang Tahun 2019 mencatat rata-rata kapasitas produksi usaha pengolahan lempok di Kecamatan Tebing Tinggi mencapai 250.000 ton per tahun. Berdasarkan latar belakang diatas peneliti tertarik untuk menganalisa keuntungan usaha pengolahan lempok durian di Kecamatan Tebing Tinggi Kabupaten Empat Lawang.

\subsection{Rumusan Masalah}

Berdasarkan latar belakang di atas, ada beberapa hal yang menarik untuk dianalisa dalam penelitian ini, yaitu:

1. Berapa biaya produksi yang dikeluarkan dalam proses pengolahan lempok durian di Kecamatan Tebing Tinggi Kabupaten Empat Lawang.

2. Berapa besar keuntungan yang diperoleh dari usaha pengolahan lempok durian di Kecamatan Tebing Tinggi Kabupaten Empat Lawang.

\subsection{Tujuan dan Kegunaan}

Tujuan yang ingin dicapai dalam penelitian ini adalah untuk:

1. Menghitung biaya produksi yang dikeluarkan dalam proses pengolahan lempok durian di Kecamatan Tebing Tinggi Kabupaten Empat Lawang.

2. Menghitung keuntungan yang diperoleh dari usaha pengolahan lempok durian di Kecamatan Tebing Tinggi Kabupaten Empat Lawang. 


\section{METODE PENELITIAN}

Penelitian ini dilaksanakan di Kecamatan Tebing Tinggi Kabupaten Empat Lawang. Waktu pelaksanaan penelitian adalah pada bulan Oktober sampai dengan Desember 2019. Metode yang digunakan pada penelitian ini adalah metode survei. Penentuan lokasi dilakukan secara sengaja (purposive) dengan pertimbangan Kecamatan Tebing Tinggi Kabupaten Empat Lawang merupakan sentra produksi lempok durian.

Penarikan contoh dilakukan dengan menggunakan metode sensus dengan cara mengambil keseluruhan populasi pengusaha pengolahan lempok durian di Kecamatan Tebing Tinggi Kabupaten Empat Lawang. Metode yang digunakan dalam pengumpulan data adalah metode wawancara langsung dan terarah dengan bantuan daftar pertanyaan, yaitu wawancara

Semua data yang diperoleh dalam penelitian ini kemudian diolah secara tabulasi lalu dihitung secara matematis dan diperjelas secara deskriptif. Untuk menjawab rumusan masalah dan tujuan dalam penelitian ini digunakan rumusrumus berikut:

\subsection{Biaya Produksi}

$$
B p=B t-B v
$$

Keterangan :

Bp : Biaya produksi (Rp)

$\mathrm{Bt} \quad$ : Biaya tetap (Rp)

Bv : Biaya variabel (Rp)

\subsection{Penerimaan}

Keterangan :

$\mathrm{Pn} \quad$ : Penerimaan $(\mathrm{Rp} / \mathrm{th})$

$\mathrm{P} \quad$ : Harga jual (Rp)

Q : Jumlah produksi yang dihasilkan (Rp)

\subsection{Keuntungan}

$\pi=P n-B p$

Keterangan :

$\pi \quad$ : Keuntungan usaha pengolahan lempok (Rp)

$\mathrm{Pn} \quad$ : Penerimaan $(\mathrm{Rp})$

Bp : Biaya Produksi (Rp)

\section{HASIL DAN PEMBAHASAN}

\subsection{Biaya Produksi Pengolahan}

\section{Lempok Durian}

Biaya produksi adalah total biaya yang dikeluarkan dalam pengolahan lempok durian, yang terdiri dari biaya tetap dan biaya variabel. Menurut Suratiyah (2015), terdapat dua jenis input berdasarkan penggunaanya yakni input tetap dan input variabel. Input tetap adalah input-input yang tidak habis dipakai dalam satu kali proses produksi sehingga biaya atas input ini dapat 
disebut sebagai biaya tetap. Sedangkan input variabel adalah input yang habis dipakai dalam satu kali proses produksi tertentu, sehingga biaya atas input ini adalah biaya variabel. Biaya produksi yang dikeluarkan dalam pengolahan lempok durian ini dapat dilihat pada tabel di bawah ini.

Tabel 3.1. Total Biaya Produksi Pengolahan Lempok Durian dikeluarkan untuk membayar upah tenaga kerja, dan membeli bahan baku, seperti durian, kayu bakar, dan gula.

\subsection{Keuntungan Pengolahan Lempok Durian}

Keuntungan usaha pengolahan lempok durian didapat dari selisih antara rata-rata total penerimaan dengan ratarata total biaya produksi yang dikeluarkan oleh petani selama satu

\begin{tabular}{|c|c|c|c|}
\hline No & Uraian & Jumlah & Rata-rata Keuntunoan \\
\hline 1. & Biaya tetap & 9.071 .606 & 1.133 .951 \\
\hline 2. & $\begin{array}{l}\text { Biaya } \\
\text { variabel }\end{array}$ & 1.200 .974 .250 & lempok durian dapat dilihat pada Tab \\
\hline & Total & 1.210 .045 .856 & 151.255 .732 \\
\hline
\end{tabular}

Sumber : Data olahan hasil penelitian, 2019

Berdasarkan data di atas diketahui bahwa rata-rata biaya produksi pengolahan lempok durian Rp. 151.255.732, yang terdiri dari biaya tetap Rp. 1.133.951 dan biaya variabel Rp. 150.121.781. Biaya tetap dalam pengolahan lempok terdiri dari biaya penyusutan alat yang digunakan untuk mengolah lempok. Peralatan yang digunakan antara lain adalah kuali, tungku drum, parang, baskom, dan kotak penyimpanan.

Selain biaya tetap, untuk menghasilkan lempok juga dibutuhkan biaya variabel, yaitu biaya yang
Tabel 3.2. Keuntungan Pengolahan Lempok Durian

\begin{tabular}{lll}
\hline No & Uraian & $\begin{array}{l}\text { Rata-rata } \\
(\mathrm{Rp} / \mathrm{Thn})\end{array}$ \\
\hline
\end{tabular}

1. Penerimaan

\begin{tabular}{cc} 
2. & 340.025 .000 \\
\hline Keuntungan & 151.255 .732 \\
\hline Sumber : Data olahan hasil penelitian, 2019
\end{tabular}

Dari Tabel 3.2. di atas diketahui bahwa rata-rata keuntungan pengolahan lempok durian Rp. 188.769.268 per tahun atau Rp. 15.730.772 per bulan. Angka ini menunjukan bahwa keuntungan dari pengolahan lempok durian ini cukup tinggi. Dengan asumsi bahwa pendapatan hanya bersumber dari pengolahan lempok durian, maka pelaku 
usaha pengolahan lempok durian memperoleh pendapatan sebesar Rp. 15.730.772 per bulan lebih tinggi dibandingkan pendapatan perkapita penduduk Indonesia yang hanya Rp. 59. 100.000 per kapita per tahun atau Rp. 4.925.000 per kapita per bulan (Badan Pusat Statistik, 2020).

Keuntungan yang cukup tinggi ini diperoleh dari hasil penjualan produk yang dihasilkan dalam pengolahan lempok. Disamping lempok itu sendiri dalam engolahannya bisa diperoleh produk sampingan berupa kerak. Ratarata produksi lempok yang dihasilkan oleh responden adalah 4.225 kilogram per tahun. Sedangkan produk sampingan berupa kerak rata-rata dihasilkan sebanyak 81 kilogram per tahun. Harga jual kerak hanya Rp25.000,- per kilogram, jauh lebih murah bila dibandingkan dengan harga lempok yang mencapai Rp80.000,- per kilogramnya. Namun penerimaan dari penjualan kerak dapat juga mendongkrak keuntungan yang diperoleh produsen lempok.

\section{KESIMPULAN DAN SARAN}

\subsection{Kesimpulan}

Berdasarkan pembahasan dari hasil penelitian ini dapat disimpulkan beberapa hal, yaitu:

1. Biaya produksi yang dikeluarkan untuk pengolahan durian menjadi lempok adalah rata-rata sebesar Rp. 151.255.732-, yang terdiri dari ratarata biaya tetap Rp. 1.133.951 dan rata-rata biaya variabel $\mathrm{Rp}$. 150.121.781,-

2. Keuntungan yang diperoleh dari usaha pengolahan durian menjadi lempok rata-rata Rp. 188.769.268 per tahun, yang diperoleh dari hasil penjualan 4.225 kilogram lempok dan 81 kilogram kerak per tahun.

\subsection{Saran}

Berdasarkan hasil penelitian dapat dilihat besarnya keuntungan yang diperoleh dari usaha pengolahan lempok dan tingginya nilai tambah yang dihasilkan. Untuk itu dapat disarankan kepada produsen lempok untuk mempertahankan usahanya dan mencoba berinovasi untuk memperoleh nilai tambah dan keuntungan yang lebih besar lagi. 


\section{DAFTAR PUSTAKA}

Anonimous. Pembuatan Dodol Durian

(Lempok).

www.bisnisUKM.com (diakses

09 Juli 2019).

BPS. 2019. Statistik Pertanian

Hortikultura Provinsi Sumatera

Selatan. Palembang.

Dinas Perindustrian dan Perdagangan.

Validasi Data Tahun 2018-2019.

Kabupaten Empat Lawang.

Djuwari. 1994. Aspek-aspek Ekonomi

Usaha Tani. Program Pasca

Sarjana. UGM. Yogyakarta.

Kementrian Koperasi dan Usaha Kecil

Menegah. 2006. Kamus Istilah.

Lestari, N. 2000. Pengembangan

Pengolahan Durian. Balai

Litbang Industri Samarinda.

Samarinda.

Mursidah. 2008. Kajian Persediaan

Bahan Baku Lempok Durian di

Kota Samarinda. Jurnal EEP

Volume 5 Nomor 2 Tahun 2008.

Sunarjono, H. 2005. Prospek Berkebun

Buah. Penebar Swadaya. Jakarta.

Sunarjono, H. 2013. Berkebun 26 Jenis

Tanaman Buah. Penebar Swadaya.

Jakarta.

Suratiyah, Ken. 2015. Ilmu Usahatani.

Penebar Swadaya. Jakarta 
